\title{
Parental psychological control: Implications for childhood physical and relational aggression
}

\author{
David A. Nelson \\ Brigham Young University - Provo, david_nelson@byu.edu \\ Nicki R. Crick
}

Follow this and additional works at: https://scholarsarchive.byu.edu/facpub

Part of the Other Social and Behavioral Sciences Commons

\section{Original Publication Citation}

Nelson, D. A., \& Crick, N. R. (2002). Parental psychological control: Implications for childhood physical and relational aggression. In B. K. Barber (Ed.), Intrusive parenting: How psychological control affects children and adolescents (pp. 161-189). Washington, D.C.: American Psychological Association (APA) Books.

\section{BYU ScholarsArchive Citation}

Nelson, David A. and Crick, Nicki R., "Parental psychological control: Implications for childhood physical and relational aggression" (2002). Faculty Publications. 4572.

https://scholarsarchive.byu.edu/facpub/4572

This Book Chapter is brought to you for free and open access by BYU ScholarsArchive. It has been accepted for inclusion in Faculty Publications by an authorized administrator of BYU ScholarsArchive. For more information, please contact ellen_amatangelo@byu.edu. 
See discussions, stats, and author profiles for this publication at: https://www.researchgate.net/publication/232516919

Parental psychological control: Implications for childhood physical and relational aggression

Article $\cdot$ January 2002

DOI: $10.1037 / 10422-006$

CITATIONS

89

2 authors, including:

David A Nelson

Brigham Young University - Provo Main Campus

57 PUBLICATIONS 3,285 CITATIONS

SEE PROFILE

Some of the authors of this publication are also working on these related projects:

Sociometric Status View project
6,206 


\title{
6
}

\section{PARENTAL PSYCHOLOGICAL CONTROL: IMPLICATIONS FOR CHILDHOOD PHYSICAL AND RELATIONAL AGGRESSION}

\author{
DAVID A. NELSON AND NICKI R. CRICK
}

Children who experience difficulties with peers also tend to experience both concurrent social-psychological difficulties and long-term negative developmental outcomes. Specifically, a significant amount of research has identified peer rejection and isolation as significant precursors to academic troubles and socially deviant behavior (DeRosier, Kupersmidt, \& Patterson, 1994; Kupersmidt, Coie, \& Dodge, 1990; Parker \& Asher, 1987; Parker, Rubin, Price, \& DeRosier, 1995). Substantial research and intervention efforts have consequently been dedicated to an understanding of the problem behaviors commonly identified as correlates or antecedents of peer rejection. Childhood aggression is one of the most significant predictors of peer rejection, and has accordingly engendered a significant amount of relevant research (see Coie \& Dodge, 1998, for a review).

Earlier research has also sought to identify the contexts in which social interaction difficulties may develop. The parent-child relationship has understandably received a significant amount of attention as one of these contexts (Hart, DeWolf, \& Burts, 1993; Hart, Olsen, Robinson, \& Mandleco, 1997; Ladd, 1992; Maccoby \& Martin, 1983). It is not unreasonable to assume that through repeated, familiar parent-child interactions, children acquire social-behavioral orientations that carry over into peer relationships (Hartup, 1979; Pettit \& Harrist, 1992). Thus, certain forms

This research was supported by a Child Psychology Training Grant Fellowship from the National Institute of Mental Health (\#T32MH15755) to the first author, and a FIRST award from the National Institute of Mental Health (\#MH53524) and a Faculty Scholars Award from the William T. Grant Foundation to the second author. Special thanks are extended to the parents and children of Project KIDS who participated in this research. 
of parenting behavior may hinder children's acquisition of social competence (Dekovič \& Janssens, 1992; Ladd, 1992; MacDonald, 1987; MacDonald \& Parke, 1984; Pettit \& Harrist, 1992; Putallaz \& Heflin, 1990).

One aspect of the parent-child relationship that can influence children's social development is the nature of parents' disciplinary control strategies. During the past several decades, parental control has received significant attention and its conceptual treatment has grown increasingly sophisticated. One important distinction assessed in recent research is the possibly unique consequences of behavioral versus psychological forms of control for child and adolescent development (Barber, 1992, 1996; Steinberg, 1990; Steinberg, Elmen, \& Mounts, 1989).

In this chapter we provide a conceptual framework and cite initial research findings regarding the possible ways in which parental psychological or coercive control (as a form of excessive behavioral control) may be differentially related to peer interaction difficulties embodied in subtypes of childhood aggression. We will give special emphasis to a relational form of childhood aggression that has received relatively little attention in the psychological literature, especially in the context of possible parenting antecedents or correlates.

We first provide an overview of current conceptualizations of childhood aggression, with emphasis on the newly emerging research regarding relational aggression. This is followed by a limited review of conceptualizations of parental control strategies (e.g., behavioral control and psychological control) and past research showing their general relation to childhood aggression. In accordance with the objectives of this volume, we give special attention to psychological control as a possible antecedent of relational forms of aggression. We present results of initial work that illuminates some of the possible parental (maternal and paternal) psychological control connections for aggression in children (both boys and girls). Finally, we conclude with a discussion of these connections and propose directions for future research.

\section{CONCEPTUALIZATIONS OF CHILDHOOD AGGRESSION}

Childhood aggression is the best known behavioral predictor of children's concurrent and future social difficulties (Coie, Dodge, \& Kupersmidt, 1990; Crick, 1996; Parker \& Asher, 1987). Accordingly, as mentioned earlier, it has garnered a substantial amount of empirical attention. However, although many important advances have been made in understanding the developmental trajectory and consequences of childhood aggression, research findings have been limited because of a traditional focus on forms of aggression most characteristic of boys (Crick, 1996; 
Crick \& Grotpeter, 1995). Specifically, childhood aggression has typically been described in terms of physical aggression, such as hitting, pushing, or verbal threats of physical harm (Berkowitz, 1993; Block, 1983; Parke \& Slaby, 1983).

Gender differences in these sorts of behaviors emerge early in life (i.e., in preschool; Loeber \& Hay, 1993; Maccoby \& Jacklin, 1980) and, before adulthood, widen substantially across development, so that by adolescence, boys far exceed girls in their commission of delinquent or violent, aggressive acts (e.g., Elliott, Ageton, Huizinga, Knowles, \& Canter, 1983; Elliott, Huizinga, \& Morse, 1987; Snyder et al., 1987). This exclusive focus on physical aggression (and related behaviors) in boys has consequently generated little information about the nature of aggression in girls (Crick \& Dodge, 1994; Robins, 1986). Underlying this dearth of research related to female aggression is the implicit assumption that girls are somehow nonaggressive (Bjorkqvist \& Niemela, 1992) and therefore do not encounter the ill effects of aggressive interaction in their peer relationships as do boys.

In recent research, however, a relational form of aggression has been identified that has been shown to be relatively more characteristic of girls (Crick \& Grotpeter, 1995). Relational aggression differs from physical forms of aggression in that it focuses on harming others through purposeful manipulation or damage to their peer relationships or feelings of inclusion (Crick, 1996; Crick, Bigbee, \& Howes, 1996; Crick \& Grotpeter, 1995). Relational aggression includes acts such as the "silent treatment," social exclusion, or threatening to end a friendship; behaviors that may all be used as a form of retaliation or as a means of getting one's way. When this form of aggression is considered, in addition to physical aggression, the prevalence of aggression in girls begins to approach that of boys (Crick \& Grotpeter, 1995). Therefore, a gender-balanced assessment of aggression is necessary, which incorporates relationally aggressive behaviors (Crick, Werner, et al., 1999). Further, systematic exploration of the construct is needed to understand its effects for the development of children (especially girls).

Because of its overt, negative consequences, physical aggression has received a substantial amount of theoretical and empirical attention (e.g., Bandura, 1973; Berkowitz, 1993; Coie \& Dodge, 1998; Dodge, 1980; Grych \& Fincham, 1990; Patterson, 1982). In contrast, research efforts have only recently begun to demonstrate the relevance of relationally aggressive behaviors for the social development and peer relations of young children. For example, children tend to view these behaviors as mean, hostile acts that inflict injury (Crick, 1995; Crick, Casas, \& Ku, 1996). This is especially true for girls, who cite relational forms of aggression as the most common angry, harmful behavior enacted in girls' peer groups. In contrast, physical aggression is the most commonly cited form of aggression in boys' peer groups (Crick, Werner, et al., 1996). 
Furthermore, past studies have indirectly shown that relational aggression may inflict significant harm. For example, girls report that they would experience significant emotional distress if they were targeted by relationally aggressive peers (Crick, 1995; Crick, Grotpeter, \& Bigbee, 2000). In addition, children who are recurrent victims of relational aggression have been shown to experience significantly more adjustment problems (e.g., depression, peer rejection, problematic friendships, loneliness, low self-esteem, and emotional distress) than their nonvictimized peers (Crick \& Bigbee, 1998; Crick et al., 1999; Crick \& Grotpeter, 1996; Grotpeter, Geiger, Nukulkij, \& Crick, 1999).

Finally, research evidence suggests that relational aggression may not only be detrimental for its recipients but also for its initiators. Specifically, relationally aggressive children report significantly higher levels of loneliness, depression, and negative self-perceptions than their nonaggressive peers (Crick \& Grotpeter, 1995). In addition, similar to physical aggression, relational aggression has been shown to be significantly related to both concurrent and future peer rejection for its initiators, regardless of gender (Crick, 1996; Crick \& Grotpeter, 1995; Crick et al., 1999).

Taken together, these studies demonstrate that relational aggression is a salient and potentially harmful activity in children's peer relationships, especially those of girls. However, studies of relational aggression are still few in number and much further work is needed. One substantial limitation of existing research is the lack of attention to parenting factors that may contribute to the development of relational aggression. Accordingly, we now turn our attention to certain forms of parental control and their demonstrated or hypothesized associations with subtypes of childhood aggression.

\section{CONCEPTUALIZATIONS OF PARENTAL CONTROL}

Parental control strategies have received widespread empirical attention over the past few decades (see Maccoby \& Martin, 1983; Peterson \& Hann, 1999; Peterson \& Rollins, 1987; Rollins \& Thomas, 1979, for reviews). To date, psychological control has been effectively contrasted with behavioral control (e.g., Barber, 1996; Barber, Olsen, \& Shagle, 1994; Steinberg, 1990; Steinberg et al., 1989), and this distinction is adopted in this chapter. The primary distinction between these forms of control is that behavioral control specifically focuses on the control of behavior, whereas psychological control is centered on the control of the child's psychological world. Furthermore, behavioral control tends to be defined quantitatively, as the consequences of such control vary significantly according to the overall level of control being exercised, given the demands of a particular context. For example, an appropriate amount of behavioral control (e.g., 
firmness, maturity demands) is viewed positively as a strategy for gaining compliance, and is commonly associated with competent child and adolescent outcomes (e.g., Baumrind, 1967, 1971; Steinberg, 1990). In contrast, parental behavioral control which is, given the specific setting, inadequate (e.g., insufficient behavioral regulation and monitoring) or excessive (e.g., punitiveness and unqualified power assertion) is commonly reported in tandem with negative child and adolescent developmental outcomes (Coie \& Dodge, 1998).

Specifically, inadequate or permissive behavioral control is commonly associated with numerous behavioral regulation problems in children and adolescents, including impulsivity, aggression, delinquency, drug use, and sexual precocity (see Barber, 1996, for a review). Singling out childhood aggression for the purposes of this chapter, probably the most outstanding evidence of an association with inadequate behavioral control, is found in the work of Patterson $(1982,1995)$. Patterson has demonstrated that children who frequently engage in physical aggression and other disruptive behaviors are inadvertently trained in these behaviors at home by their parents. Specifically, parents provide negative reinforcement for these undesirable behaviors via inconsistent discipline (i.e., dropping demands for compliance when the child reacts aversively). Thus, parents in these situations fail to provide sufficient behavioral control to counteract the development and maintenance of aggressive or disruptive child behaviors. Furthermore, from this viewpoint, aggressive or disruptive children generalize their experiences with parents to the peer group, expecting that their misbehavior will continue to help them achieve desired outcomes and avoid unwanted consequences.

There is also a substantial amount of empirical research that posits that excessive behavioral control, in the form of punitive and power-assertive discipline, is associated at least to some degree with childhood and adolescent physical aggression (see Coie \& Dodge, 1998, for a recent perspective). Decades ago, Hoffman (1960) warned parents against the use of unqualified power assertion (commands, threats, deprivations, and physical force), declaring that such methods evoked feelings of opposition and hostility toward parents that would interfere with the proper internalization of control. Furthermore, from a social-learning perspective, parents' use of power assertion may serve as a model that the child might use in relationships with others (e.g., peers). In fact, findings from relevant studies affirm this hypothesis, showing that children reared in a power-assertive manner are more likely to expect that aggressive strategies will help them get their way with peers (e.g., Hart, DeWolf, \& Burts, 1992; Hart, Ladd, \& Burleson, 1990). Thus, childhood aggression (only physical aggression has been studied) has commonly been reported in past research as a correlate or consequence of maladaptive forms of parental behavioral control. 
In contrast to behavioral control, psychological control has, from its inception as a construct (e.g., Schaefer, 1959, 1965a, 1965b), almost exclusively been construed as a negative form of control, interfering with the developing child's need for psychological autonomy. Parallel with Schaefer's work, the idea of parental intrusion on the psychological and emotional development of children is also found in the early typological work of Baumrind (1966), who specifically warned against the use of guilt-induction and manipulation of the love relationship with the child. However, psychological control has only recently received focused attention, beginning with the work of Steinberg and colleagues (Steinberg, 1990; Steinberg et al., 1989; Steinberg, Lamborn, Dornbusch, \& Darling, 1992; Steinberg, Mounts, Lamborn, \& Dornbusch, 1991), who have contrasted the adverse effects of psychological control with the positive effects of appropriate behavioral control on adolescent development. Steinberg (1990) described these seemingly paradoxical findings (opposite findings with two forms of control) as follows: "Adolescents appear to be adversely affected by psychological control-the absence of 'psychological autonomy'-but positively influenced by behavioral control-the presence of 'demandingness' " (p. 274). Finally, one of the most recent definitions of psychological control (Barber, 1996) clearly accentuates its negative effects by defining it as

a rather insidious type of control that potentially inhibits or intrudes upon psychological development through manipulation and exploitation of the parent-child bond (e.g., love withdrawal and guilt induction), negative, affect-laden expressions and criticisms (e.g., disappointment and shame), and excessive personal control (e.g., possessiveness, protectiveness). (p. 3297)

Accordingly, a construct of such negative import certainly warrants further empirical attention to fully assess its impact on various facets of child development. Barber (1996) outlined two issues that are useful in theorizing about the effects of psychological control on child development: (a) how psychological control differs from other types of parental control, and (b) whether psychological control has unique relations to various child and adolescent outcomes. The evidence cited previously provides ample justification, at a conceptual level, for a distinction between behavioral and psychological control. This distinction is especially evident in the comparison of appropriate behavioral control with psychological control (e.g., Steinberg, 1990). Furthermore, in chapter 2 (this volume), Barber and Harmon note that numerous other research efforts have begun to probe for differential associations of psychological and varying levels of behavioral control with unique child and adolescent outcomes. One promising avenue of continued research is the possibly unique links between parental psychological control and variants of aggressive behavior. 
Moreover, little is known about the unique effects of psychological control on the development of younger children. Barber (1996) hypothesized that the effects of psychological control may be most pronounced for adolescents (rather than younger children). This reasoning is based on the developmental need of adolescents to achieve greater autonomy as part of identity development (Erikson, 1968; Marcia, 1980), a developmental task that is hindered by high levels of parental psychological control. However, Barber (1996) also acknowledged that psychological control may be generally defined as "intrusion into the developing child's self-expression - whatever the form of expression that might be" (p. 3315). Accordingly, the psychological control construct deserves further empirical attention and exploration in work with younger children.

Finally, past studies have also demonstrated the possible moderating effect of the gender of the child or parent in the practice of psychological control (see chapters 8 and 9 , this volume, for reviews). For example, Barber's (1996) series of studies found interactions between gender of parent and gender of child, wherein findings were obtained for certain parent-child dyads (e.g., mother-daughter, mother-son, father-daughter, father-son) but not for others. The inclusion of gender as a factor is especially important in the exploration of factors related to the development of physical and relational aggression, which tend to be uniquely related to gender norms.

\section{EXPLAINING RELATIONAL AGGRESSION: THE CASE FOR PSYCHOLOGICAL CONTROL}

The role of parenting styles and other family factors in the development of childhood physical aggression has received extensive empirical attention (see Coie \& Dodge, 1998; Hart et al., 1997, for reviews). For example, in regard to parenting style dimensions, past research shows consistent associations between physical aggression and a lack of authoritative features, such as parental responsiveness, warmth, and involvement. In addition, physical aggression has also been linked to permissive (e.g., inadequate behavioral control, condoning of aggression) or authoritarian (e.g., coercive discipline in the form of physical punishment, verbal hostility, and lack of reasoning) parenting (see Hart, Nelson, Robinson, Olsen, \& McNeillyChoque, 1998; MacKinnon-Lewis et al., 1994, for reviews).

In contrast, very little research at this time suggests consistent associations between any particular parenting practices and the development of relational aggression. In addition, little research has specifically examined the possibly unique associations of different parenting variables to aggression subtypes (e.g., to physical versus relational; Crick, Werner, 1999). However, findings from a number of recent studies indicate that the study of parental 
psychological control may hold significant promise for enhancing our understanding of the development of relationally aggressive behavior patterns.

First, initial research regarding the nature of relationally aggressive children's dyadic peer and parent relationships suggests that the development of relational aggression may be associated with a relatively intense focus on the importance of relationships. For example, relationally aggressive children are more likely than their peers to characterize their dyadic friendships as relatively high in intimacy, jealousy, and desires for exclusivity (e.g., not wanting to "share" their friends with others; Grotpeter \& Crick, 1996). Second, in contrast with developmental norms in which children begin to individuate themselves from their parents as they approach adolescence (Blos, 1962; Steinberg, 1990; Sullivan, 1953), Grotpeter, Crick, and O'Brien (1996) found that preadolescent (fifth-and sixth-grade) relationally aggressive children reported being significantly closer to their mothers (on intimacy and companionship dimensions) than their nonaggressive counterparts, and did not differ in this respect from younger (third- and fourth-grade) relationally aggressive or nonaggressive children. Finally, relative to their peers, relationally aggressive children report significantly higher levels of exclusivity with both their fathers and mothers (e.g., their parents would rather they stay home with them than do something with friends; Grotpeter, 1997). Taken together, these findings indicate that relationally aggressive children tend to describe their friendships and parent-child relationships as overly exclusive and perhaps enmeshed.

Based on these findings, we have hypothesized that, at an early age, relationally aggressive children, within the context of exclusive, enmeshed relationships with parents, may learn that close, intimate relationships are highly valued and, perhaps, that the manipulation of such relationships is an effective means for achieving one's goals (see Crick, Werner, et al., 1999). Such a hypothesis stresses that relationally aggressive children may have parents who manipulate their intense parent-child relationship in ways suggested by the psychological control construct (e.g., manipulation of the love relationship). Indeed, several of the theoretically relevant characteristics of psychological control (see Barber, 1996) closely resemble relationally aggressive behaviors. For example, love withdrawal and erratic emotional behavior are two dimensions of psychological control that may focus on manipulation of the love relationship ("love-oriented" control; Becker, 1964). These strategies may be most effective in a parent-child relationship that is overly exclusive or enmeshed. Love withdrawal strategies set a conditional tone for the relationship (e.g., being less friendly with the child when he or she does not see things your way), similar to the strategies relationally aggressive children use with their peers. Erratic emotional behavior is a fitting complement to such a relationship, whereby feelings may suddenly change according to compliance to demands. Thus, high levels of parental 
psychological control may be especially predictive of the development of relationally aggressive behaviors in children.

Studies of gender differences in children's social interactions indicate that this hypothesized association between psychological control and relational aggression may be most relevant for girls, who, following prescribed gender norms, are typically described as more invested in the development and maintenance of dyadic relationships (Block, 1983; Crick \& Grotpeter, 1995). For example, Maccoby (1990) contrasted the peer interaction styles of boys and girls. Girls are described as having an "enabling" interactive style that contributes to the establishment and maintenance of dyadic interactions in which verbal give-and-take and positive affirmation are key elements. In contrast, boys are described as having a "restrictive" interactive style in that their peer interactions are defined by the establishment and maintenance of hierarchies (group-oriented focus). Accordingly, because of their sensitivity in regard to the maintenance of dyadic relationships, girls who are raised by psychologically controlling parents may be more vulnerable to the effects of such parenting (which threatens their dyadic ties with parents) and may be more likely to generalize their experiences to the peer group. Thus, we have hypothesized that parental psychological control may be uniquely related to the development of relational aggression and that this association might be most pronounced for girls.

Finally, as suggested earlier, this association may vary significantly for girls or boys, depending on the gender of the parent in question. This possibility is adequately demonstrated in previous research findings of psychological control (e.g., Barber, 1996). In short, appreciation of genderdifferentiated parenting, and the corresponding particularities of father-son, father-daughter, mother-son, and mother-daughter relationships, may be necessary to fully understand family relationships and child outcomes (e.g., Collins \& Russell, 1991; Cowan, Cowan, \& Kerig, 1993; Dornbusch, 1989; Russell \& Saebel, 1997; Steinberg, 1987, 1990).

\section{EXPLORING PSYCHOLOGICAL CONTROL AND AGGRESSION SUBTYPES}

Beyond our own preliminary, exploratory research with a middle childhood sample (third-grade children), which will be described below, to our knowledge only Hart and colleagues (e.g., Hart et al., 1998, 2000; Yang et al., 2001) have specifically evaluated the association between psychological control and subtypes of childhood aggression. These studies have also included various measures of behavioral control (conceptualized as coercion or excessive behavioral control) as a point of contrast. That work is also 
unique in that samples of Russian and Chinese preschool children and their parents have been the focus.

The results of the research with Russian preschoolers (Hart et al,, 1998, 2000) showed that, contrary to our expectations, maternal psychological control was significantly related to overt (physical bullying and instrumental) aggression but not to relational aggression (for both boys and girls). Paternal psychological control was unrelated to aggression. Furthermore, maternal coercion was associated with overt aggression for boys and both overt and relational forms of aggression for girls. Paternal coercion was related to overt aggression for both boys and girls. These findings suggest that psychological control may not be uniquely tied to relational aggression in preschoolers, at least in the Russian culture.

In contrast, using similar measures but more sophisticated statistical analyses (e.g., structural equation modeling), Yang et al. (2001) found relationships between maternal and paternal psychological control and relational aggression in Chinese preschoolers. In particular, mothers' psychological control was associated with girls' physical and relational aggression and boys' physical aggression. In contrast, maternal coercion was unrelated to childhood aggression. Fathers' psychological control was also associated with girls' relational aggression. Finally, fathers' coercion was related to both girls' and boys' physical and relational aggression.

Results with the Chinese sample suggest that psychological control may indeed be related to the development of relationally aggressive tendencies, at least in preschool girls. However, firm conclusions cannot be established without further research. In any case, given the cultural contexts of these studies, it is uncertain whether any of the results will generalize to preschoolers in Western culture. Furthermore, different findings may be obtained with samples of children who are older (e.g., in middle childhood) than the preschoolaged children targeted by Hart and colleagues. In short, older children and adolescents may be the most vulnerable to the effects of psychological control, as the developmental need for autonomy increases, and more definitive findings may therefore be obtained by using such age groups in research design.

In this chapter, we share preliminary results of an initial attempt to explore the influence of psychological control on subtypes of aggression in a middle childhood, U.S. sample. Similar to previous studies, we rely on a unidimensional model of psychological control that includes several key theoretical characteristics that are likely related to relational aggression. In addition, we seek to further explore possibly unique effects of mothers versus fathers in the practice of psychological control. Based on previous research, wherein findings for psychological control varied according to the nature of the particular parent-child dyad (mother-daughter, mother-son, fatherdaughter, father-son; e.g., Barber, 1996), we speculate that psychological 
control by mothers and fathers may be differentially linked to aggression outcomes-both physical and relational—for boys and girls.

\section{THE RESEARCH}

The sample was composed of 115 third-grade children ( 58 boys, 57 girls) from two school districts in a large Midwestern city. These children constituted a normative sample drawn from a larger longitudinal study (beginning at third grade) of the development and consequences of physical and relational forms of childhood aggression. Approximately $69 \%$ of the sample was European American, $16 \%$ of the sample was African American, and the remaining $15 \%$ was a mix of other ethnicities (Hmong, Latino, Native American, Asian, Ethiopian, and biracial children). Mothers of all of these children participated in a home-based interview in which they completed a self-report measure of psychological control strategies they use with their child. More detail about this measure is given below. Numerous other measures were also completed during the interview but are not a part of this study. These interviews were led by trained graduate or undergraduate interviewers. Biological fathers also took part in 63 families and completed the psychological control measure. The socioeconomic status of participating families was varied, ranging from low to high.

\section{Assessment of Aggression Subtypes}

To obtain continuous aggression scores for each child in the study, a peer sociometric questionnaire was administered in participating children's elementary school classrooms. Written parental consent was obtained for each child before administering the sociometric. The particular sociometric instrument used was the Children's Social Behavior Scale-Peer Form (CSBSP), a group-administered peer-nomination measure of aggression developed in past research (see Crick, 1997; Crick \& Grotpeter, 1995) in which five

items assess physical aggression (e.g., children who hit or kick others) and five items assess relational aggression (e.g., children who try to make kids not like a certain person by spreading rumors about him or her or talking behind his or her back). In addition, four items assess prosocial behavior (e.g., children who do nice things for others) and serve as positive filler items. Only the aggression items were used in the exploratory analyses.

During the administration of this instrument, children were instructed to name up to three classmates who best fit the description given for each item. A class roster was provided to assist them in this process. For each item, the number of nominations that each child received was standardized within each classroom. Finally, items belonging to separate subscales were 
summed to yield two subscale continuous scores for each child (physical aggression, relational aggression). Evidence for the internal consistency and test-retest reliability of this measure has been documented in previous studies (e.g., Crick, 1997). Finally, all of the children who participated in the classroom sociometric were extended the opportunity to participate with their families in the home interview portion of the study.

\section{Assessment of Parental Behavioral and Psychological Control}

Mothers and fathers independently completed a self-report parenting questionnaire that included items from the Parenting Practices Questionnaire (PPQ; Robinson, Mandleco, Olsen, \& Hart, 1995) and the Parental Psychological Control measure (PPC; Hart \& Robinson, 1995). The items selected from the PPQ reflected dimensions of authoritative and authoritarian parenting styles. For the use of this study, we selected the authoritarian dimensions, made up of verbal hostility and corporal punishment, which are used as separate dimensions of coercive control in the analyses that follow. These control dimensions and their associated items are presented in appendix 6A. Parents responded to all of these items using a 5-point Likert-type response scale anchored by never (1) and always (5).

We used a parental self-report rather than a child-report measure to assess psychological control, based on Barber's (1996) speculation that younger research participants may not be mature enough to differentiate the types of control that might intrude on their psychological autonomy (see chapter 5, this volume, for an example of children's ability to report on parental behavior). The PPC was conceptualized based on dimensions of psychological control recently developed for adolescents by Barber (1996) and includes the items used in versions of Psychological Control ScaleYouth Self Report (PCS-YSR), except that those items have been adjusted to reflect a parent self-report rather than a child's report of parent behavior.

For the purposes of this chapter, we used an abbreviated list of the eight items that Barber (1996) cited in the final version of the PCS-YSR to form our psychological control variable. Of the original eight items, two represent the "constraining verbal expression" dimension and were not included in our questionnaire. 'Another item reflecting love withdrawal was also not included in our analyses as it was copied incorrectly from the original measure and therefore did not adequately represent the original

\footnotetext{
Based on a multidimensional view of psychological control, those dimensions that appeared conceptually most similar to the relational aggression construct were selected for use as part of a much larger study of childhood aggression. Accordingly, and also because of time constraints, we did not assess the "constraining verbal expression" items in our study.
} 
item. Accordingly, we settled on a five-item scale of psychological control, which is presented in appendix 6A. This scale reflects the invalidating feelings, personal attack, and love withdrawal dimensions of psychological control. Finally, parents responded to the psychological control items with the same response scale described previously (5-point Likert-type response scale anchored by never (1) and always (5)).

Reliability was separately evaluated for mothers and fathers for each of these scales. For mother reports, Cronbach's alpha was $.65, .84$, and .68 for the psychological control, corporal punishment, and verbal hostility scales, respectively. For father reports, Cronbach's alpha was $.54, .75$, and .60 for the psychological control, corporal punishment, and verbal hostility scales, respectively.

In prelude to this and later sections it should be noted that, because of constraints imposed by the small size of the overall sample, the choice of analyses and results presented in this chapter constitute more of an exploratory and therefore limited test of the association between parental control and aggression subtypes. The limitations are especially apparent in the context of comparing parent-child dyads of different gender compositions, as cell sizes for the various dyads, especially father-child dyads, are small. Past research shows that the most appropriate manner to provide evidence for differences between the four parent-child dyads is to document a gender of parent by gender of child interaction (e.g., Jacklin, 1981). However, in a review of relevant research, Russell and Saebel (1997) noted that sample size is crucial to the detection of a possible gender interaction effect, with samples of less than 100 families typically showing no evidence of an interaction (and the inverse finding for most samples above this number). Accordingly, null or marginal findings must be interpreted with caution, because a restricted sample size can contribute to Type II errors.

Because direct comparison of mothers' and fathers' use of the psychological and coercive control strategies in this sample were based on small sample sizes ( $n=27$ for boys, $n=33$ for girls), we did not anticipate a significant interaction. Consistent with our expectations, an exploratory 2 (gender of parent) $\times 3$ (control type: psychological control, corporal punishment or verbal hostility) $\times 2$ (gender of child) repeated measures ANOVA (in which gender of parent and control type served as within-subjects variables, gender of child was the between-subjects variable, and control scores served as the dependent variables) did not yield a significant interaction for psychological control or the separate components of coercive control.

However, some findings were gleaned from follow-up analyses. First, we conducted a 2 (gender of parent) $\times 2$ (gender of child) repeated measures ANOVA (in which gender of parent served as the within-subjects variable, gender of child was the between-subjects variable, and psychological control 
TABLE 6-1

Means, Standard Deviations, and Ranges for Parental Control Variables by Parent-Child Dyad

\begin{tabular}{lcccc}
\hline & \multicolumn{4}{c}{ Parent-Child Dyad } \\
\cline { 2 - 5 } & $\begin{array}{c}\text { Mother- } \\
\text { Son } \\
(n=58)\end{array}$ & $\begin{array}{c}\text { Mother- } \\
\text { Daughter } \\
(n=57)\end{array}$ & $\begin{array}{c}\text { Father- } \\
\text { Son } \\
(n=28)\end{array}$ & $\begin{array}{c}\text { Father- } \\
\text { Daughter } \\
(n=35)\end{array}$ \\
Control Variable & 1.59 & 1.51 & 1.63 & 1.66 \\
\hline $\begin{array}{l}\text { Psychological control } \\
\quad \text { Mean } \\
\quad(S D)\end{array}$ & $(0.58)$ & $(0.37)$ & $(0.53)$ & $(0.38)$ \\
$\begin{array}{l}\text { Corporal punishment } \\
\quad \text { Mean }\end{array}$ & 1.62 & 1.25 & 1.44 & 1.40 \\
$\quad(S D)$ & $(0.61)$ & $(0.36)$ & $(0.43)$ & $(0.39)$ \\
$\begin{array}{l}\text { Verbal hostility } \\
\text { Mean }\end{array}$ & 2.22 & 2.09 & 2.04 & 2.06 \\
$(S D)$ & $(0.68)$ & $(0.58)$ & $(0.61)$ & $(0.31)$ \\
\hline
\end{tabular}

scores served as the dependent variables). A main effect for gender of parent revealed that fathers $(M=1.61 ; S D=0.45)$ use significantly higher levels of psychological control than mothers $(M=1.46, S D=0.36)$ with their offspring; $F(1,58)=6.4, p<.05$, and no effect was found for gender of child, suggesting that boys and girls at this age may not differ in total exposure to parental psychological control.

Finally, to take advantage of full sample sizes to better detect mothers' possible differential use of control strategies with their children (to include mothers who were excluded from the repeated measures ANOVAs), we conducted a series of one-way ANOVAs in which child gender was the independent variable and maternal control strategies (psychological control, corporal punishment, verbal hostility) served as dependent variables. One significant finding emerged from these analyses. Mothers were found to use significantly more corporal punishment with sons than daughters: $F(1,114)=$ $15.3, p<.001$. Means and standard deviations for the control strategy scales for each parent-child dyad are provided in Table 6-1.

\section{Correlational Analyses by Dyad}

Following these analyses and the attendant concern over statistical power issues enumerated previously, we elected to conduct further analyses by dyad. Although this approach cannot firmly establish sex-related differences (Jacklin, 1981), it can suggest possible differences (Russell \& Saebel, 1997). The first step in these analyses focused on intercorrelation matrices for all parent-child dyads, which are displayed in Tables 6-2 through 6-5. Verbal hostility and corporal punishment are listed separately as elements of coercive control. Beginning with Table 6-2, results showed that maternal corpo- 
TABLE 6-2

Intercorrelations Between Boys' Aggression Subtypes and Maternal Psychological and Coercive Control

\begin{tabular}{lcccc}
\hline & $\begin{array}{c}\text { Relational } \\
\text { Aggression }\end{array}$ & $\begin{array}{c}\text { Maternal } \\
\text { Corporal } \\
\text { Punishment }\end{array}$ & $\begin{array}{c}\text { Maternal } \\
\text { Verbal } \\
\text { Hostility }\end{array}$ & $\begin{array}{c}\text { Maternal } \\
\text { Psychological } \\
\text { Control }\end{array}$ \\
\hline Physical aggression & $.81^{\star \star \star}$ & $.45^{\star \star \star}$ & $.25+$ & .15 \\
Relational aggression & & $.40^{\star \star}$ & $.24+$ & .19 \\
Maternal corporal punishment & & & $.49^{\star \star \star}$ & $.56^{\star \star \star}$ \\
Maternal verbal hostility & & & & $.48^{\star \star \star}$ \\
\hline
\end{tabular}

$+p<.10 ;{ }^{*} p<.05 ; * * p<.01 ;{ }^{* * *} p<.001$.

TABLE 6-3

Intercorrelations Between Girls' Aggression Subtypes and Maternal Psychological and Coercive Control

\begin{tabular}{lcccc}
\hline & $\begin{array}{c}\text { Relational } \\
\text { Aggression }\end{array}$ & $\begin{array}{c}\text { Maternal } \\
\text { Corporal } \\
\text { Punishment }\end{array}$ & $\begin{array}{c}\text { Maternal } \\
\text { Verbal } \\
\text { Hostility }\end{array}$ & $\begin{array}{c}\text { Maternal } \\
\text { Psychological } \\
\text { Control }\end{array}$ \\
\hline Physical aggression & $.40^{\star \star *}$ & .12 & -.13 & $-.23+$ \\
Relational aggression & & .20 & .17 & -.03 \\
Maternal corporal punishment & & & $.27^{\star}$ & $.24+$ \\
Maternal verbal hostility & & & & $.25^{\star}$ \\
\hline
\end{tabular}

$+p<.10 ;{ }^{*} p<.05 ;{ }^{* *} p<.01 ;{ }^{* * *} p<.001$.

TABLE 6-4

Intercorrelations Between Boys' Aggression Subtypes and Paternal Psychological and Coercive Control

\begin{tabular}{lcccc}
\hline & $\begin{array}{c}\text { Relational } \\
\text { Aggression }\end{array}$ & $\begin{array}{c}\text { Paternal } \\
\text { Corporal } \\
\text { Punishment }\end{array}$ & $\begin{array}{c}\text { Paternal } \\
\text { Verbal } \\
\text { Hostility }\end{array}$ & $\begin{array}{c}\text { Paternal } \\
\text { Psychological } \\
\text { Control }\end{array}$ \\
\hline Physical aggression & $.81^{\star * *}$ & $-.43^{*}$ & .15 & .09 \\
Relational aggression & & $-.38^{*}$ & .15 & .03 \\
Paternal corporal punishment & & & .21 & .16 \\
Paternal verbal hostility & & & & $.45^{*}$ \\
\hline
\end{tabular}

$+p<.10 ;{ }^{*} p<.05 ;{ }^{* *} p<.01 ;{ }^{* * *} p<.001$.

ral punishment was significantly and positively correlated with both physical and relational aggression in boys. There was also a trend for maternal verbal hostility to be associated with both forms of aggression in boys. In contrast, paternal corporal punishment was significantly and negatively related to both forms of aggression in boys (see Table 6-4). 
TABLE 6-5

Intercorrelations Between Girls' Aggression Subtypes and Paternal Psychological and Coercive Control

\begin{tabular}{lcccc}
\hline & $\begin{array}{c}\text { Relational } \\
\text { Aggression }\end{array}$ & $\begin{array}{c}\text { Paternal } \\
\text { Corporal } \\
\text { Punishment }\end{array}$ & $\begin{array}{c}\text { Paternal } \\
\text { Verbal } \\
\text { Hostility }\end{array}$ & $\begin{array}{c}\text { Paternal } \\
\text { Psychological } \\
\text { Control }\end{array}$ \\
\hline Physical aggression & $.40^{\star \star \star}$ & $.36^{\star}$ & -.22 & $.30+$ \\
Relational aggression & & .16 & .01 & $.55^{\star \star \star}$ \\
Paternal corporal punishment & & & -.11 & .12 \\
Paternal verbal hostility & & & & .00 \\
\hline
\end{tabular}

$+p<.10 ;{ }^{*} p<.05 ;{ }^{* *} p<.01 ; * * * p<.001$.

For girls, maternal psychological control was marginally and negatively related to physical aggression (see Table 6-3). In comparison, girls' physical aggression was significantly and positively related to paternal corporal punishment and marginally and positively related to paternal psychological control. Finally, girls' relational aggression was moderately correlated with paternal psychological control (see Table 6-5). These contrasting findings suggest evidence of gender-differentiated effects of parent-child interaction and the need to separately consider the various combinations of parentchild dyads.

\section{Hierarchical Regressions}

In the next step of analysis, several sets of hierarchical regression analyses were conducted to evaluate the relative contributions of parental coercive control and psychological control to the prediction of concurrent levels of children's physical and relational aggression. These analyses were conducted separately for each of the possible parent-child dyads (motherson $(n=58)$, mother-daughter $(n=57)$, father-son $(n=28)$, fatherdaughter $(n=35))$. Physical and relational aggression continuous scores served as dependent variables and parental psychological control and coercive control (both verbal hostility and corporal punishment dimensions) scores served as independent variables. Each of the analyses were performed twice-the second set of equations had the order of entry of the independent variables reversed. This allowed for an assessment of the relatively unique contribution of maternal psychological control. All results are documented in Tables 6-6 through 6-9, but comment about findings of the second set of equations (after order of entry has been reversed) are only made if the findings were significantly different from those gained in the first set of equations. 
TABLE 6-6

$R^{2}$ Values for Regression Equations Predicting Boys' Aggression Subtypes From Maternal Psychological and Coercive Control

\begin{tabular}{|c|c|c|c|c|}
\hline \multirow[b]{2}{*}{ Dependent Variable } & \multicolumn{2}{|c|}{$\begin{array}{c}\text { Maternal Psychological } \\
\text { Control } \\
\text { Entered at Step } 1\end{array}$} & \multicolumn{2}{|c|}{$\begin{array}{l}\text { Maternal Coercive } \\
\text { Control } \\
\text { Entered at Step } 1\end{array}$} \\
\hline & $\begin{array}{c}R^{2} \\
\text { for Maternal } \\
\text { Psychological } \\
\text { Control }\end{array}$ & $\begin{array}{c}R^{2} \text { Change } \\
\text { for Maternal } \\
\text { Coercive } \\
\text { Control }\end{array}$ & $\begin{array}{c}R^{2} \\
\text { for Maternal } \\
\text { Coercive } \\
\text { Control }\end{array}$ & $\begin{array}{c}R^{2} \text { Change } \\
\text { for Maternal } \\
\text { Psychological } \\
\text { Control }\end{array}$ \\
\hline $\begin{array}{l}\text { Physical aggression } \\
\text { Relational aggression }\end{array}$ & $\begin{array}{l}.02 \\
.04\end{array}$ & $\begin{array}{l}.19^{\star \star} \\
.13^{\star}\end{array}$ & $\begin{array}{l}.20^{\star \star} \\
.16^{\star \star}\end{array}$ & $\begin{array}{l}.02 \\
.00\end{array}$ \\
\hline
\end{tabular}

$+p<.10 ;{ }^{*} p<.05 ;{ }^{* *} p<.01 ;{ }^{* * *} p<.001$.

\section{MATERNAL CONTRIBUTIONS TO PHYSICAL AND RELATIONAL AGGRESSION}

In the first set of equations for mother-son dyads, maternal psychological control scores were entered at step one and maternal coercive control scores were entered as a block at step two. This allowed us to evaluate the degree to which maternal coercive control uniquely predicted physical or relational aggression beyond that predicted by maternal psychological control (see Table 6-6 for $R^{2}$ values). Results of step one analyses showed that maternal psychological control was unrelated to physical or relational aggression for boys. However, in step two analyses, maternal coercive control significantly predicted both physical aggression, $F(3,54)$ change $=6.7, p<$. 01 ; and relational aggression, $F(3,54)$ change $=4.3, p<.05$; above and beyond maternal psychological control.

Next, in the first set of similar equations for mother-daughter dyads (see Table 6-7 for $R^{2}$ values), step one analyses showed that maternal psychological control was marginally related to physical aggression, $F(1$, $55)=3.1, p<.10$; and unrelated to relational aggression for girls. Maternal coercive control was also unrelated to both physical aggression and relational aggression for girls at step two in the analyses.

\section{PATERNAL CONTRIBUTIONS TO PHYSICAL AND RELATIONAL AGGRESSION}

In the first set of similar equations for father-son dyads (see Table 6-8 for $R^{2}$ values), step one analyses showed that paternal psychological control was unrelated to physical or relational aggression in boys. However, in step two 
TABLE 6-7

$R^{2}$ Values for Regression Equations Predicting Girls' Aggression Subtypes From Maternal Psychological and Coercive Control

\begin{tabular}{|c|c|c|c|c|}
\hline \multirow[b]{2}{*}{ Dependent Variable } & \multicolumn{2}{|c|}{$\begin{array}{c}\text { Maternal Psychological } \\
\text { Control } \\
\text { Entered at Step } 1\end{array}$} & \multicolumn{2}{|c|}{$\begin{array}{l}\text { Maternal Coercive } \\
\text { Control } \\
\text { Entered at Step } 1\end{array}$} \\
\hline & $\begin{array}{c}R^{2} \\
\text { for Maternal } \\
\text { Psychological } \\
\text { Control }\end{array}$ & $\begin{array}{c}R^{2} \text { Change } \\
\text { for Maternal } \\
\text { Coercive } \\
\text { Control }\end{array}$ & $\begin{array}{c}R^{2} \\
\text { for Maternal } \\
\text { Coercive } \\
\text { Control }\end{array}$ & $\begin{array}{c}R^{2} \text { Change } \\
\text { for Maternal } \\
\text { Psychological } \\
\text { Control }\end{array}$ \\
\hline $\begin{array}{l}\text { Physical aggression } \\
\text { Relational aggression }\end{array}$ & $\begin{array}{l}.05+ \\
.00\end{array}$ & $\begin{array}{l}.04 \\
.06\end{array}$ & $\begin{array}{l}.04 \\
.05\end{array}$ & $\begin{array}{l}.06+ \\
.01\end{array}$ \\
\hline
\end{tabular}

$+p<.10 ; " p<.05 ; * * p<.01 ; " * * p<.001$.

analyses, paternal coercive control significantly predicted physical aggression, $F(3,24)$ change $=3.7, p<.05$; and marginally predicted relational aggression, $F(3,24)$ change $=2.9, p<.10$; above and beyond paternal psychological control.

In the first set of similar equations for father-daughter dyads (see Table 6-9 for $R^{2}$ values), paternal psychological control entered at step one marginally predicted physical aggression, $F(1,33)=3.3, p<.10$, but significantly predicted relational aggression, $F(1,33)=14.1, p<.001$, for girls. Furthermore, at step two, paternal coercive control marginally added to the prediction of girls' physical aggression, $F(3,31)$ change $=2.9$, $p<$ .10 , but failed to add to the prediction of relational aggression for girls. Finally, when the order of entry was reversed, findings were slightly different in that paternal psychological control no longer remained marginally predictive of girls' physical aggression.

TABLE 6-8

$R^{2}$ Values for Regression Equations Predicting Boys' Aggression Subtypes From Paternal Psychological and Coercive Control

\begin{tabular}{|c|c|c|c|c|}
\hline \multirow[b]{2}{*}{ Dependent Variable } & \multicolumn{2}{|c|}{$\begin{array}{c}\text { Paternal Psychological } \\
\text { Control } \\
\text { Entered at Step } 1\end{array}$} & \multicolumn{2}{|c|}{$\begin{array}{c}\text { Paternal Coercive } \\
\text { Control } \\
\text { Entered at Step } 1\end{array}$} \\
\hline & $\begin{array}{c}R^{2} \\
\text { for Paternal } \\
\text { Psychological } \\
\text { Control }\end{array}$ & $\begin{array}{c}R^{2} \text { Change } \\
\text { for Paternal } \\
\text { Coercive } \\
\text { Control }\end{array}$ & $\begin{array}{c}R^{2} \\
\text { for Paternal } \\
\text { Coercive } \\
\text { Control }\end{array}$ & $\begin{array}{c}R^{2} \text { Change } \\
\text { for Paternal } \\
\text { Psychologica } \\
\text { Control }\end{array}$ \\
\hline $\begin{array}{l}\text { Physical aggression } \\
\text { Relational aggression }\end{array}$ & $\begin{array}{l}.01 \\
.00\end{array}$ & $\begin{array}{l}.24^{*} \\
.19+\end{array}$ & $\begin{array}{l}.24^{*} \\
.19+\end{array}$ & $\begin{array}{l}.00 \\
.00\end{array}$ \\
\hline
\end{tabular}

$+p<.10 ;{ }^{*} p<.05 ;{ }^{* *} p<.01 ;{ }^{* * *} p<.001$. 
TABLE 6-9

$R^{2}$ Values for Regression Equations Predicting Girls' Aggression Subtypes From Paternal Psychological and Coercive Control

\begin{tabular}{|c|c|c|c|c|}
\hline \multirow[b]{2}{*}{ Dependent Variable } & \multicolumn{2}{|c|}{$\begin{array}{c}\text { Paternal Psychological } \\
\text { Control } \\
\text { Entered at Step } 1\end{array}$} & \multicolumn{2}{|c|}{$\begin{array}{l}\text { Paternal Coercive } \\
\text { Control } \\
\text { Entered at Step } 1\end{array}$} \\
\hline & $\begin{array}{c}R^{2} \\
\text { for Paternal } \\
\text { Psychological } \\
\text { Control }\end{array}$ & $\begin{array}{c}R^{2} \text { Change } \\
\text { for Paternal } \\
\text { Coercive } \\
\text { Control }\end{array}$ & $\begin{array}{c}R^{2} \\
\text { for Paternal } \\
\text { Coercive } \\
\text { Control }\end{array}$ & $\begin{array}{c}R^{2} \text { Change } \\
\text { for Paternal } \\
\text { Psychological } \\
\text { Control }\end{array}$ \\
\hline $\begin{array}{l}\text { Physical aggression } \\
\text { Relational aggression }\end{array}$ & $\begin{array}{l}.09+ \\
.30^{\star \star \star}\end{array}$ & $\begin{array}{l}.14+ \\
.01\end{array}$ & $\begin{array}{l}.16+ \\
.03\end{array}$ & $\begin{array}{l}.07 \\
.28^{\star \star \star *}\end{array}$ \\
\hline
\end{tabular}

$+p<.10 ;{ }^{*} p<.05 ; * * p<.01 ; * * * p<.001$.

\section{DISCUSSION}

These findings, though limited in their scope and significance, do show that coercive control and psychological control, as conceptualized in this chapter, were relatively distinct in their links to childhood forms of aggression, with very little overlap displayed in the regression equation results. Further, where findings were obtained for coercive control, correlations showed that corporal punishment appeared to be the central influence in most of these findings, because verbal hostility was not significantly associated with aggression subtypes in any of the dyads.

In addition, unique findings were obtained for each of the parent-child dyads. Starting with mother-son dyads, maternal coercive control was significantly associated with both physical and relational forms of aggression. Correlations showed that higher levels of maternal corporal punishment were positively associated with more aggression of both forms in boys. In contrast, for father-son dyads, coercive control was significantly associated with physical aggression, but in a qualitatively different manner from the mother-son associations. Specifically, correlations clarified that higher levels of paternal corporal punishment were associated with less physical aggression in boys. Finally, for girls, the only significant finding was obtained for father-daughter dyads. Results showed that higher levels of paternal psychological control were positively associated with relational aggression in girls.

This chapter focuses on a fundamental problem-childhood aggression-and the possible influence of parental control strategies in the development of aggression subtypes (e.g., physical and relational aggression). In particular, we sought to explore the plausible relation between parental psychological control and childhood relational aggression, two constructs that have only recently begun to receive focused empirical attention. This 
is an important area to explore, as studies demonstrate that relational aggression, like physical aggression, is linked to social and psychological difficulties for perpetrators and their victims (see Crick, Werner, et al., 1999, for a review). Consequently, there is a significant need to understand the possible precursors to relational aggression. The definition of parental psychological control suggests an intuitive connection with relational aggression (Hart et al., 1998, 2000; Yang et al., 2001).

Indeed, elements of psychological control (e.g., love withdrawal, erratic emotional behavior) parallel the essence of relational aggression, in which relationships are manipulated or threatened. Accordingly, a child raised by psychologically controlling parents may be more likely to adopt relationally aggressive strategies in her interaction with peers. The fact that parents of schoolage children in this study acknowledge the practice of psychological control demonstrates that some parents may perceive these strategies to be effective in gaining compliance. Hence, this study provides further evidence that psychological control may influence child development from an early age. Furthermore, linking psychological control to relational aggression would suggest one more reason to consider this form of parental control as negative and therefore worthy of continued empirical attention. With these ideas as our framework, we explored our hypotheses with a sample of thirdgrade children and their parents. Consistent with our primary hypothesis, we found parental psychological control to be related to relational aggression in middle childhood, at least for girls.

In addition to this primary finding, we also found, consistent with past studies, that the association between various parental control strategies and childhood aggression varied by the gender composition of the particular parent-child dyad. These findings add further credence to the position, stated earlier, that appreciation of gender-differentiated parenting may further understanding of the influence of family relationships on various child outcomes (e.g., Cowan et al., 1993; Russell \& Saebel, 1997). Such an emphasis also corresponds with surging interest in fatherhood research, which considers the possibly unique influence of fathers, relative to mothers, on their children (e.g., Lamb, 1997).

Speaking of fathers, we return to the main finding linking psychological control and relational aggression, which was unique to fatherdaughter dyads. This relatively strong finding suggests that fathers may contribute to the development or maintenance of relationally aggressive tendencies in their daughters. The strength of this finding was somewhat surprising, given the rather small number of father-daughter dyads $(n=$ 35). Accordingly, because of small cell sizes, for this and other dyads, our analyses should be considered exploratory in nature. Indeed, sample size may be a significant factor in the rather limited findings for psychological control in other parent-child dyads. Still, consistent with findings of earlier 
studies, the results demonstrate that negative forms of parental control (both coercive and psychological control) are significantly associated with childhood aggression. Furthermore, we are confident that future studies will replicate and further define the link between psychological control and relational aggression.

In many ways, the finding for fathers and daughters is notable. First, in this and previous studies by Hart and colleagues (Hart et al., 1998, 2000; Yang et al., 2001), no link between parental psychological control and relational aggression was obtained for boys. There may be several explanations for this. One possible rationale was mentioned earlier: Girls are typically described as more focused on the development and maintenance of dyadic relationships (Block, 1983; Crick \& Grotpeter, 1995). Accordingly, girls may be particularly sensitive to the effects of psychological control, a parenting style that may leave the impression that the parent-child relationship is constantly in a state of flux. Girls may also have greater difficulties establishing autonomy, given their greater sensitivity to relationship disturbances (Cross \& Madsen, 1997; Leadbeater, Blatt, \& Quinlin, 1995) and this may further heighten their susceptibility to the negative effects of psychological control.

The finding for fathers and daughters is also unique when one considers the research that consistently shows that fathers tend to be more involved with sons than with daughters (Parke, 1996; Pleck, 1997). Accordingly, past research on the role of fathers in child development has focused predominantly on father-son relationships, consistent with the emphasis in past years on sex-role development and identification with the same-sex parent (Biller \& Kimpton, 1997). Gradually, however, the role of fathers in their daughters' lives has been taken more seriously, and empirical evidence to this end has accumulated (Biller \& Kimpton, 1997). This study adds impetus to the study of father-daughter relationships and the possibly unique influences at work. In particular, the study of paternal influence may significantly contribute to our understanding of relationally aggressive girls.

It is also notable that, overall, fathers in this study were also found to be more psychologically controlling than mothers, a finding inconsistent with a trend indicating higher levels of maternal psychological control in the few studies that have tested parental sex differences (see chapter 9, this volume). Again, these findings collectively provide further evidence of a role for fathers in child maladjustment, a possibility that past developmental research has tended to neglect (Phares, 1997; Phares \& Compas, 1992). More recent research shows that a father who is dominating and controlling in parent-child interaction constrains positive interaction and, accordingly, his child's ability to learn effective social skills (Biller \& Kimpton, 1997). Relational aggression may be just one of the many manifestations of social difficulty related to improper control strategies used by fathers. 
This study joins those studies presented in chapters 5,7 , and 8 (this volume) in showing linkages between parental psychological control and younger children's functioning. It also suggests further evidence for the impact of psychological control on childhood aggression, specifically. However, the meager amount of studies with early and middle-childhood samples (Hart et al., 1998, 2000; Yang et al., 2001) demonstrates a need for replication and further research in this area. Future studies should also incorporate a broader age range (e.g., adolescents) to examine how these associations may vary by parent and child gender as well as age of the child.

Furthermore, studies that incorporate larger samples, more sophisticated statistical approaches, and more complete models of possible variable relationships will be beneficial. For example, the recent study by Yang et al. (in press), noted earlier, used structural equation modeling to analyze how child temperament may interact with parental control strategies and childhood aggression outcomes (see chapter 5 , this volume, for a similar approach). In short, there are many exciting possibilities for further research in this domain, which we hope will increase our understanding of the development of relational aggression and eventually suggest possible prevention or intervention strategies, such as parenting education, for better child social development outcomes.

\section{REFERENCES}

Bandura, A. (1973). Aggression: A social leaming theory analysis. New York: Prentice-Hall.

Barber, B. K. (1992). Family, personality, and adolescent problem behaviors. Journal of Marriage and the Family, 54, 69-79.

Barber, B. K. (1996). Parental psychological control: Revisiting a neglected construct. Child Development, 67, 3296-3319.

Barber, B. K., Olsen, J. A., \& Shagle, S. C. (1994). Associations between parental psychological and behavioral control and youth internalized and externalized behaviors. Child Development, 65, 1120-1136.

Baumrind, D. (1966). Effects of authoritative control on child behavior. Child Development, 37, 887-907.

Baumrind, D. (1967). Child care practices anteceding three patterns of preschool behavior. Genetic Psychology Monographs, 75, 43-88.

Baumrind, D. (1971). Current patterns of parental authority. Developmental Psychology, 4, 1-103.

Becker, W. C. (1964). Consequences of different kinds of parental discipline. In M. L. Hoffman \& W. W. Hoffman (Eds.), Review of child development research (Vol. 1, pp. 169-208). New York: Russell Sage Foundation. 
Berkowitz, L. (1993). Aggression: Its causes, consequences, and control. New York: Academic Press.

Biller, H. B., \& Kimpton, J. L. (1997). The father and the school-aged child. In M. E. Lamb (Ed.), The role of the father in child development (3rd ed., pp. 143-161). New York: Wiley \& Sons.

Bjorkqvist, K., \& Niemela, P. (1992). New trends in the study of female aggression. In K. Bjorkqvist \& P. Niemela (Eds.), Of mice and women: Aspects of female aggression (pp. 1-15). San Diego, CA: Academic Press.

Block, J. H. (1983). Differential premises arising from differential socialization of the sexes: Some conjectures. Child Development, 54, 1335-1354.

Blos, P. (1962). On adolescence, a psychoanalytic interpretation. New York: Free Press of Glencoe.

Coie, J. D., \& Dodge, K. A. (1998). Aggression and antisocial behavior. In W. Damon (Series Ed.) \& N. Eisenberg (Vol. Ed.), Handbook of child psychology. Vol. 3: Social, emotional, and personality development (5th ed., pp. 779-862). New York: Wiley \& Sons.

Coie, J. D., Dodge, K. A., \& Kupersmidr, J. A. (1990). Peer group behavior and social status. In S. R. Asher \& J. D. Coie (Eds.), Peer rejection in childhood (pp. 309-337). New York: Cambridge University Press.

Collins, W. A., \& Russell, G. (1991). Mother-child and father-child relationships in middle childhood and adolescence: A developmental analysis. Developmental Review, 11, 99-136.

Cowan, P. A., Cowan, C. P., \& Kerig, P. K. (1993). Mothers, fathers, sons, and daughters: Gender differences in family formation and parenting style. In P. A. Cowan, D. Field, D. A. Hansen, A. Skolnick, \& G. E. Swanson (Eds.), Family, self, and society: Toward a new agenda for family research (pp. 165-195). Hillsdale, NJ: Erlbaum.

Crick, N. R. (1995). Relational aggression: The role of intent attributions, feelings of distress, and provocation type. Development and Psychopathology, 7, 313-322.

Crick, N. R. (1996). The role of overt aggression, relational aggression, and prosocial behavior in the prediction of children's future social adjustment. Child Development, 67, 2317-2327.

Crick, N. R. (1997). Engagement in gender normative versus nonnormative forms of aggression: Links to social-psychological adjustment. Developmental Psychology, 33, 610-617.

Crick, N. R., \& Bigbee, M. A. (1998). Relational and overt forms of peer victimization: A multi informant approach. Journal of Consulting and Clinical Psychology, $66,337-347$.

Crick, N. R., Bigbee, M. A., \& Howes, C. (1996). Gender differences in children's normative beliefs about aggression: How do I hurt thee? Let me count the ways. Child Development, 67, 1003-1014.

Crick, N. R., Casas, J. F., \& Ku, H. (1999). Relational and physical forms of peer victimization in preschool. Developmental Psychology, 35, 375-385. 
Crick, N. R., \& Dodge, K. A. (1994). A review and reformulation of social information-processing mechanisms in children's social adjustment. Psychological Bulletin, $115,74-101$.

Crick, N. R., \& Grotpeter, J. K. (1995). Relational aggression, gender, and socialpsychological adjustment. Child Development, 66, 710-722.

Crick, N. R., \& Grotpeter, J. K. (1996). Children's treatment by peers: Victims of relational and overt aggression. Development and Psychopathology, 8, 367-380.

Crick, N. R., Grotpeter, J. K., \& Bigbee, M. A. (2000). Relationally and physically aggressive children's intent attributions and feelings of distress for relational and instrumental peer provocations. Manuscript under review.

Crick, N. R., Werner, N. E., Casas, J. F., O'Brien, K. M., Nelson, D. A., Grotpeter, J. K., \& Markon, K. (1999). Childhood aggression and gender: A new look at an old problem. In D. Bernstein (Ed.), Nebraska symposium on motivation: Vol. 45. Gender and motivation (pp. 75-141). Lincoln: Nebraska University Press.

Cross, S. E., \& Madsen, L. (1997). Models of the self: Self-construals and gender. Psychological Bulletin, 122, 5-37.

DeRosier, M. E., Kupersmidt, J. B., \& Patterson, C. J. (1994). Children's academic and behavioral adjustment as a function of the chronicity and proximity of peer rejection. Child Development, 1799-1813.

Dekovič, M., \& Janssens, J. M. A. M. (1992). Parents' child-rearing style and child's sociometric status. Developmental Psychology, 28, 925-932.

Dodge, K. A. (1980). Social cognition and children's aggressive behavior. Child Development, 51, 162-170.

Dornbusch, S. M. (1989). The sociology of adolescence. Annual Review of Sociology, $15,233-259$.

Elliott, D. S., Ageton, S., Huizinga, D., Knowles, B., \& Canter, R. (1983). The prevalence and incidence of delinquent behavior: 1976-1980. Boulder, CO: Behavioral Research Institute.

Elliott, D. S., Huizinga, D., \& Morse, B. J. (1987). Self-reported violent offending: A descriptive analysis of juvenile violent offenders and their offending careers. Journal of Interpersonal Violence, 1, 472-514.

Erikson, E. E. (1968). Identity: Youth and crisis. New York: Norton.

Grotpeter, J. K. (1997). Relational aggression, overt aggression, and family relationships. Unpublished doctoral dissertation, University of Illinois at UrbanaChampaign.

Grotpeter, J. K., \& Crick, N. R. (1996). Relational aggression, overt aggression, and friendship. Child Development, 67, 2328-2338.

Grotpeter, J. K., Crick, N. R., \& O'Brien, K. M. (1996, April). Relationally and overtly aggressive children's relationships with their mothers. Paper presented at the biennial meeting of the Conference on Human Development, Birmingham, Alabama. 
Grotpeter, J. K., Geiger, T., Nukulkij, P., \& Crick, N. R. (1999). Friendships of relationally and overtly victimized children: With friends like this, who needs enemies? Manuscript submitted for publication.

Grych, J. H., \& Fincham, F. D. (1990). Marital conflict and children's adjustment: A cognitive-contextual framework. Psychological Bulletin, 108, 267-290.

Hart, C. H., DeWolf, M., \& Burts, D. C. (1992). Linkages among preschoolers' playground behavior, outcome expectations, and parental disciplinary strategies. Early Education and Development, 3, 265-283.

Hart, C. H., DeWolf, M., \& Burts, D. C. (1993). Parental disciplinary strategies and preschoolers' play behavior in playground settings. In C. H. Hart (Ed.), Children on playgrounds: Research perspectives and applications (pp. 271-313). Albany: State University of New York Press.

Hart, C. H., Ladd, G. W., \& Burleson, B. R. (1990). Children's expectations of the outcomes of social strategies: Relations with sociometric status and maternal disciplinary styles. Child Development, 61, 127-137.

Hart, C. H., Nelson, D. A., Robinson, C. C., Olsen, S. F., \& McNeilly-Choque, M. K. (1998). Overt and relational aggression in Russian nursery-schoolage children: Parenting style and marital linkages. Developmental Psychology, 34, 687-697.

Hart, C. H., Nelson, D. A., Robinson, C. C., Olsen, S. F., McNeilly-Choque, M. K., Porter, C. L., \& Mckee, T. R. (2000). Russian parenting styles and family processes: Linkages with subtypes of victimization and aggression. In K. A. Kerns, J. M. Contreras, \& A. M. Neal-Barnett (Eds.), Family and peers: Linking two social worlds (pp. 47-84). Westport, CT: Praeger.

Hart, C. H., Olsen, S. F., Robinson, C. C., \& Mandleco, B. L. (1997). The development of social and communicative competence in childhood: Review and a model of personal, familial, and extra familial processes. In B. R. Burleson (Ed.), Communication yearbook (Vol. 20, pp. 305-373). Thousand Oaks, CA: Sage.

Hart, C. H., \& Robinson, C. C. (1995). Parental psychological control: An instrument for early childhood. Unpublished manuscript.

Hartup, W. W. (1979). The social worlds of childhood. American Psychologist, 34, 944-950.

Hoffman, M. L. (1960). Power assertion by the parent and its impact on the child. Child Development, 31, 129-143.

Jacklin, C. N. (1981). Methodological issues in the study of sex-related differences. Developmental Review, 1, 266-273.

Kupersmidt, J. B., Coie, J. D., \& Dodge, K. A. (1990). The role of poor peer relationships in the development of later disorders. In S. R. Asher \& J. D. Coie (Eds.), Peer rejection in childhood (pp. 274-305). Cambridge: Cambridge University Press.

Ladd, G. W. (1992). Themes and theories: Perspectives on processes in family-peer relationships. In R. D. Parke \& G. W. Ladd (Eds.), Family-peer relationships: Modes of linkage (pp. 3-34). New Jersey: Erlbaum. 
Lamb, M. E. (1997). Fathers and child development: An introductory overview and guide. In M. E. Lamb (Ed.), The role of the father in child development (3rd ed.). New York: Wiley \& Sons.

Leadbeater, B. J., Blatt, S. J., \& Quinlin, D. M. (1995). Gender-linked vulnerabilities to depressive symptoms, stress, and problem behaviors in adolescents. Journal of Research in Adolescence, 5, 1-29.

Loeber, R., \& Hay, D. F. (1993). Developmental approaches to aggression and conduct problems. In M. Rutter \& D. F. Hay (Eds.), Development through life: A handbook for clinicians (pp. 488-516). Oxford, England: Blackwell.

Maccoby, E. E. (1990). Gender and relationships. American Psychologist, 45, $512-$ 520.

Maccoby, E. E., \& Jacklin, C. N. (1980). Sex differences in aggression: A rejoinder and reprise. Child Development, 51, 964-980.

Maccoby, E. E., \& Martin, J. A. (1983). Socialization in the context of the family: Parent-child interaction. In E. M. Hetherington (Ed.) \& P. H. Mussen (Series Ed.), Handbook of child psychology, Vol. 4: Socialization, personality, and social development (pp. 1-102). New York: Wiley.

MacDonald, K. (1987). Parent-child physical play with rejected, neglected, and popular boys. Developmental Psychology, 23, 705-711.

MacDonald, K., \& Parke, R. D. (1984). Bridging the gap: Parent-child play interaction and peer interactive competence. Child Development, 55, 1265-1277.

MacKinnon-Lewis, C., Volling, B. L., Lamb, M. E., Dechman, K., Rabiner, D., \& Curtner, M. E. (1994). A cross-contextual analysis of boys' social competence: From family to school. Developmental Psychology, 30, 325-333.

Marcia, J. E. (1980). Identity in adolescence. In J. Abelson (Ed.), Handbook of adolescent psychology (pp. 159-187). New York: Wiley.

Parke, R. D. (1996). Fatherhood. Cambridge, MA: Harvard University Press.

Parke, R. D., \& Slaby, R. G. (1983). The development of aggression. In P. H. Mussen (Series Ed.) \& M. Hetherington (Vol. Ed.), Handbook of child psychology (4th ed., Vol. 4, pp. 547-642).

Parker, J. G., \& Asher, S. R. (1987). Peer acceptance and later personal adjustment: Are low accepted children "at risk"? Psychological Bulletin, 102, 357-389.

Parker, J. G., Rubin, K. H., Price, J. M., \& DeRosier, M. E. (1995). Peer relationships, child development, and adjustment: A developmental psychopathology perspective. In D. Cicchetti \& D. J. Cohen (Eds.), Developmental psychopathology. Vol. 2: Risk, disorder, \& adaptation (pp. 96-161). New York: Wiley \& Sons.

Patterson, G. R. (1982). Coercive family processes. Eugene, OR: Castilia Press.

Patterson, G. R. (1995). Coercion-A basis for early age of onset for arrest. In J. McCord (Ed.), Coercion and punishment in long-term perspective (pp. 81-105). New York: Cambridge University Press.

Peterson, G. W., \& Hann, D. (1999). Socializing parents and children in families. In S. Steinmetz, M. Sussman, \& G. W. Peterson (Eds.), Handbook of marriage and the family (rev. ed.; pp. 327-370). New York: Plenum Press. 
Peterson, G. W., \& Rollins, B. C. (1987). Parent-child socialization. In M. Sussman $\&$ S. K. Steinmetz (Eds.), Handbook of marriage and the family (pp. 471-507). New York: Plenum Press.

Pettit, G. S., \& Harrist, A. W. (1992). Children's aggressive and socially unskilled playground behavior with peers: Origins in early family relations. In $\mathrm{C}$. $\mathrm{H}$. Hart (Ed.), Children on playgrounds: Research perspectives and applications (pp. 240-270). Albany: State University of New York Press.

Phares, V. (1997). Psychological adjustment, maladjustment, and father-child relationships. In M. E. Lamb (Ed.), The role of the father in child development (3rd ed., pp. 261-283). New York: Wiley \& Sons.

Phares, V., \& Compas, B. E. (1992). The role of fathers in child and adolescent psychopathology: Make room for daddy. Psychological Bulletin, 111, 387-412.

Pleck, J. H. (1997). Paternal involvement: Levels, sources, and consequences. In M. E. Lamb (Ed.), The role of the father in child development (3rd ed., pp. 66-103).

Putallaz, M., \& Heflin, A. H. (1990). Parent-child interaction. In S. R. Asher \& J. D. Coie (Eds.), Peer rejection in childhood (pp. 189-216). Cambridge: Cambridge University Press.

Robins, L. (1986). The consequences of conduct disorders in girls. In D. Olweus, J. Block, \& M. Radke-Yarrow (Eds.), Development of antisocial and prosocial behavior (pp. 385-409). New York: Academic Press.

Robinson, C. C., Mandleco, B., Olsen, S. F., \& Hart, C. H. (1995). Authoritative, authoritarian, and permissive parenting practices: Development of a new measure. Psychological Reports, 77, 819-830.

Rollins, B. C., \& Thomas, D. L. (1979). Parental support, power, and control techniques in the socialization of children. In W. R. Burr, R. Hill, F. I. Nye, \& I. L. Reiss (Eds.), Contemporary theories about the family: Vol. 1. Research based theories (pp. 317-364). New York: Free Press.

Russell, A., \& Saebel, J. (1997). Mother-son, mother-daughter, father-son, and father-daughter: Are they distinct relationships? Developmental Review, 17, $111-147$.

Schaefer, E. S. (1959). A circumplex model for maternal behavior. Journal of Abnormal Social Psychology, 59, 226-235.

Schaefer, E. S. (1965a). Children's reports of parental behavior: An inventory. Child Development, 36, 413-424.

Schaefer, E. S. (1965b). A configurational analysis of children's reports of parent behavior. Joumal of Consulting Psychology, 29, 552-557.

Snyder, H., Finnegan, T., Nimick, E., Sickmund, D., Sullivan, D., \& Tierney, N. (1987). Juvenile Court Statistics, 1984. Pittsburgh, PA: National Center for Juvenile Justice.

Steinberg, L. (1987). The impact of puberty on family relations: Effects of pubertal status and pubertal timing. Developmental Psychology, 23, 451-460. 
Steinberg, L. (1990). Autonomy, conflict, and harmony in the family relationship. In S. S. Feldman \& G. R. Elliot (Eds.), At the threshold: The developing adolescent (pp. 255-276). Cambridge, MA: Harvard University Press.

Steinberg, L., Elmen, J. D., \& Mounts, N. S. (1989). Authoritative parenting, psychological maturity, and academic success among adolescents. Child Development, 60, 1424-1436.

Steinberg, L., Lamborn, S. D., Dornbusch, S. M., \& Darling, N. (1992). Impact of parenting practices on adolescent achievement: Authoritative parenting, school involvement, and encouragement to succeed. Child Development, 63, 1266-1281.

Steinberg, L., Mounts, N. S., Lamborn, S. D., \& Dornbusch, S. M. (1991). Authoritative parenting and adolescent adjustment across various ecological niches. Journal of Research on Adolescence, 1, 19-36.

Sullivan, H. S. (1953). The interpersonal theory of psychiatry. New York: Norton.

Yang, C., Hart, C. H., Nelson, D. A., Olsen, S. F., Robinson, C. C., \& Jin, S. (2001). Measuring mothers' and fathers' coercion and psychological control: Linkages with preschoolers' aggression in a Chinese sample. Manuscript under review. 


\section{APPENDIX 6A \\ LIST OF CONTROL DIMENSIONS AND ASSOCIATED ITEMS}

Corporal Punishment (3 items)

1. I use physical punishment as a way of disciplining my child.

2. I guide my child by physical punishment more than by reason.

3. I spank when my child is disobedient.

Verbal Hostility (3 items)

1. I explode in anger toward my child.

2. I argue with my child.

3. I yell or shout when my child misbehaves.

Psychological Control (5 items)

1. I try to change how my child feels or thinks about things.*

2. I blame my child for other family members' problems.**

3. I bring up my child's past mistakes when criticizing him/her.**

4. I am less friendly with my child when he/she does not see things my way. $\dagger$

5. If my child has hurt my feelings, I stop talking to him/her until he/she pleases me again. $\dagger$

\footnotetext{
*Invalidating feelings dimension

"Personal attack dimension

${ }^{\dagger}$ Love withdrawal dimension

Source: Items adopted for use from "Parental Psychological Control: Revisiting a Neglected Construct," by B. K. Barber, 1996, Child Development, 62, p. 3316. Some items reproduced with permission of authors and publisher from: Robinson, C. C., Mandleco, B., Olsen, S. F., \& Hart, C. $\mathrm{H}$. Authoritative, authoritarian, and permissive parenting practices: Development of a new measure. Psychological Reports, 1995, 77, 819-830. (C) Psychological Reports 1995.
} 